Nama : Nyoman Ayu Shandy C

Email : shandycatarina@gmail.com

\title{
Contingency Theory and The Role of Mediating Effect
}

Contingency theory adalah sebuah teori tentang bagaimana sebuah perusahaan dipengaruhi oleh faktor eksternal dan bagaiman suatu perusahaan bisa bertahan dengan cara menjadi fleksibel dan adaptif terhadap perubahan lingkungan eksternal. Teori ini memandang bahwa lingkungan eksternal merupakan determinan utama firm performance. Secara khusus, teori ini menekankan pada pertanyaan tentang apakah dan di mana variabel kontingensi berkontribusi pada firm performance. Oleh karena itu, perusahaan tidak hanya perlu memperoleh dan mengembangkan sumber daya mereka tetapi juga perlu meningkatkan kemampuan untuk menghadapi turbulensi. Organisasi berbasis kontingensi mendapatkan keunggulan kompetitif melalui penilaian lingkungan bisnis mereka dan menetapkan strategi, yang sesuai. pendekatan kontingensi mendorong pengelola UKM dan organisasinya merespons dengan melakukan pelatihan. (Pratono, Strategic orientation and information technological turbulence: Contingency perspective in SMEs, 2016) Teori kontingensi telah muncul sebagai lensa untuk mengeksplorasi hubungan antara penyelarasan strategis dan praktik manajemen kualitas juga membutuhkan identifikasi sejumlah faktor atau variabel kontingensi (McAdam, Miller, \& McSorley, 2019)

Turbulensi lingkungan merupakan proses yang mengubah dampak variabel independen pada firm performance dalam konteks teori kontingensi. Variabel moderasi dapat membawa perubahan arah pada slope atau koefisien variabel independen. Semakin tinggi SO maka perfomancenya akan semakin tinggi. Jika sebuah perusahaan berorientasi pada peluang maka perusahaan akan mendapat performance yang bagus. Jika kondisi turbulance tinggi dan berorientasi pada supply harga akan turun. (Pratono, Strategic orientation and information technological turbulence: Contingency perspective in SMEs, 2016) Hasil regresi dengan variabel moderasi teknologi informasi menunjukkan bahwa pengaruh perilaku pengambilan risiko terhadap kinerja perusahaan kurang efektif dalam kondisi turbulensi teknologi informasi yang tinggi. (Pratono, Does firm performance increase with risk-taking behavior under information technological turbulence?: Empirical evidence from Indonesian SMEs, 2018) Jika perusahaan memberi autonomi pada karyawan maka akan dapat performance yg lebih bagus. Autonomi berdampak positif ke firm performance. Jadi semakin tinggi autonomi maka firm performance akan meningkat. Dengan syarat hanya jika technologycal turbulancenya rendah namun jika technology tuebulancenya tiggi maka akan berefek negatif bagi perusahaan tersebut. (Pratono, 2018)

Agent-system contingency theory merupakan teori umum dari keputusan manajerial dalam konteks supply chain dan pemasaran industri (SCIM). Teori tersebut bertumpu pada dua asumsi dasar yaitu otoritas keputusan dan juga rasionalitas terbatas. dan menyatakan bahwa ciri kepribadian yang relevan dari human agent di SCIM dan properti tingkat sistem antar perusahaan atau antar perusahaan properti dapat secara bersamaan dan interaktif mempengaruhi keputusan dan tindakan manajerial di SCIM. Analisis korelasional (correlational analyses) misalnya analisis regesi dapat digunakan untuk menguji suatu 
hubungan yang diusulkan antara hasil keputusan sebagai variabel dependen. Sedangkan agent- and system-level sebagai variabel independen bersama dengan interaksinya. (Tangpong, Hung, \& Li, 2019)

Dalam jurnal Why do cities adopt smart technologies? Contingency theory and evidence from the United States menjelaskan bahwa variabel dependen yang digunakan merupakan indeks yang mengukur sejauh mana kota bisa mengadopsi smart technology. Sedangkan untuk variabel independen yang digunakan terdiri dari dua set variabel keputusan manajemen; 1 ) insentif apa yang memotivasi untuk mengadopsi teknologi kota pintar; dan 2) kendala yang dihadapi. Artikel ini menggunakan model Akaike Information Criterion Stepwise OLS karena variabel dependen the extent to which cities deploy smart technologies merupakan variabel berkelanjutan. (Araral, 2020)

Mediating effect merupakan efek mediasi yang relatif untuk bisa mengidentifikasi kondisi batas untuk setiap mediator misalnya kemampuan adaptif dengan pengurangan oportunisme dan juga dalam kaitannya dengan hubungan fungsional antara ikatan sosial dan kinerja perusahaan. Mediation effect kapabilitas yang adaptif dan juga oportunisme pemasok dimana kemampuan adaptif berkaitan dengan fleksibilitas perusahaan dalam hal beradaptasi dengan perubahan pasar dan juga secara khusus dapat mencerminkan kemampuan perusahaan untuk mengimbangkan sumber daya internal dengan permintaan eksternal. (Zhu, Su, \& Shou, 2017) Peran dari mediating effect ini dalam jurnal ini adalah tentang mediating effect antar kepercayaan dan kapabilitas harga yang mana kepercayaan memiliki pengaruh yang cukup signifikan terhadap kemempuan menjual serta kemampuan dalam penetapan harga. (Pratono, 2018)

Mediating effect dari kualitas untuk kepercayaan komunikasi yang tinggi pada jejearing sosial turut berkontribusi untuk menghasilkan nilai untuk pengembangan produk baru melalui komunikasi. Namun, hubungan dalam jaringan tidak selalu berdampak langsung terhadap prestasi kerja karena pengaruh yang didapat sebagian dimediasi oleh variabel lain. Kepercayaan juga sangat penting dalam mempromosikan bentuk organisasi adaptif untuk mengurangi konflik yang berbahaya juga dalam membangun hubungan jejaring sosial. Keterlibatan jaringan ini mengisi kesenjangan dalam kepercayaan antara perusahaan dan stakeholder mereka yang bergantung pada pengurangan biaya berdasarkan pengalaman untuk perusahaan. Pembangunan kepercayaan adalah elemen dasar bagi perusahaan, distibutor dan juga pemasok untuk bisa saling memahami. Mediating effect dalam kemempuan menjual mengacu pada sejauh mana perusahaan dapat mengelola berbagai produk penjualan kepada pelanggan yang akhirnya akan bisa mengembangan hubungan yang baik serta kuat antara perusahaan dan pelanggan dan bisa memperkirakan potensi yang ada pada pelanggan secara efektif. Perusahaan yang terus semakin bergantung terhadap sumber sumber eksternal dari pemasok serta pada mitra akan memiliki semakin banyak peluang untuk mencapai kinerja yang lebih efektif dan inofatif. (Pratono, 2018)

Mediating effect dari adanya kapabilitas penetapan harga menunjukkan bagaimana kapabilitas suatu perusahaan untuk dapat menetapkan harga yang bisa mencerminkan nilai dari pelanggannya. Hal yang sangat penting untuk mendorong kemampuan perusahaan untuk menghadapi terjadinya penurunan motivasi konsumen mengenai strategi harga yang 
rendah adalah dengan mengelola mitra mereka untuk membuat peningkatan yang lebih lanjut dari kemampuan pemasaran suatu perusahaan. Menjadi perusahaan dengan tingkat penjualan yang sangat tinggi juga merupakan hal yang didorong oleh reputasi dari perusahaan tersebut yang mana telah menginvestasikan sejumlah sumber dayanya pada jejaring sosial dan juga pada bidang periklanan. (Pratono, 2018)

Pengujian dalam jurnal ini bertujuan untuk menjelaskan bagaimana pembelajaran antar organisasi dapat memberikan efek mediasi yang positif terhadap hubungan antara orientasi kewirausahaan, keunggulan kompetitif perusahaan dan juga tentang orientasi dalam pemasaran perusahaan. Pembelajaran antar organisasi juga tidak hanya merupakan sumber daya yang berharga untuk mencapai keunggulan kompetitif namun juga dapat membantu perusahaan untuk dapat memanfaatkan orientasinya pada kewirausahaan dan juga orientasi terhadap pasar ke dalam keunggulan kompetitif. (Pratono, Darmasetiawan, Yudiarso, \& Jeong, 2019)

\section{Bibliography}

Araral, E. (2020). Why do cities adopt smart technologies? Contingency theory and evidence from the United States. Cities, 106, 102873.

McAdam, R., Miller, K., \& McSorley, C. (2019). Towards a contingency theory perspective of quality management in enabling strategic alignment. Int. J. Production Economics, 207, 195-209.

Pratono, A. H. (2016). Strategic orientation and information technological turbulence: Contingency perspective in SMEs. Business Process Management Journa, 22(2), 368-382.

Pratono, A. H. (2018). Does firm performance increase with risk-taking behavior under information technological turbulence?: Empirical evidence from Indonesian SMEs. Journal of Risk Finance, 194, 361-378.

Pratono, A. H. (2018). From social network to firm performance: The mediating effect of trust,selling capability and pricing capability. Management Research Review, 41(6), 680-700.

Pratono, A. H., Darmasetiawan, N. K., Yudiarso, A., \& Jeong, B. (2019). Achieving sustainable competitive advantage through green entrepreneurial orientation and market orientation: The role of inter-organizational learning. The Bottom Line, 32(1), 2-15.

Pratono, A. H., Ratih, R. V., \& Arshad, D. (2018). Does Entrepreneurial Autonomy Foster SME Growth. Journal of Technological Behaviour Science, 3, 170-178.

Tangpong, C., Hung, K.-T., \& Li, J. (2019). Toward an agent-system contingency theory for behavioral supply chain and. Industrial Marketing Management, 83, 134-147.

Zhu, W., Su, S., \& Shou, Z. (2017). Social ties and firm performance: The mediating effect of adaptive capability and supplier opportunism. Journal of Business Research, 78, 226-232. 


\section{Bibliography}

Araral, E. (2020). Why do cities adopt smart technologies? Contingency theory and evidence from the United States. Cities, 106, 102873.

McAdam, R., Miller, K., \& McSorley, C. (2019). Towards a contingency theory perspective of quality management in enabling strategic alignment. Int. J. Production Economics, 207, 195-209.

Pratono, A. H. (2016). Strategic orientation and information technological turbulence: Contingency perspective in SMEs. Business Process Management Journa, 22(2), 368-382.

Pratono, A. H. (2018). Does firm performance increase with risk-taking behavior under information technological turbulence?: Empirical evidence from Indonesian SMEs. Journal of Risk Finance, 194, 361-378.

Pratono, A. H. (2018). From social network to firm performance: The mediating effect of trust,selling capability and pricing capability. Management Research Review, 41(6), 680-700.

Pratono, A. H., Darmasetiawan, N. K., Yudiarso, A., \& Jeong, B. (2019). Achieving sustainable competitive advantage through green entrepreneurial orientation and market orientation: The role of inter-organizational learning. The Bottom Line, 32(1), 2-15.

Pratono, A. H., Ratih, R. V., \& Arshad, D. (2018). Does Entrepreneurial Autonomy Foster SME Growth. Journal of Technological Behaviour Science, 3, 170-178.

Tangpong, C., Hung, K.-T., \& Li, J. (2019). Toward an agent-system contingency theory for behavioral supply chain and. Industrial Marketing Management, 83, 134-147.

Zhu, W., Su, S., \& Shou, Z. (2017). Social ties and firm performance: The mediating effect of adaptive capability and supplier opportunism. Journal of Business Research, 78, 226-232. 